\title{
Preface to the Special Issue: New studies on early modern humans from Okinawa, South Japan
}

\author{
Yousuke KAIFU $^{1,2 *}$, Yuji MizoGUCHI ${ }^{1}$ \\ ${ }^{1}$ Department of Anthropology, National Museum of Nature and Science, Tokyo 169-0073, Japan \\ ${ }^{2}$ Department of Biological Sciences, The University of Tokyo, Tokyo 113-0033, Japan
}

From 2005 to 2009 , the second author organized a research project entitled 'Synthetic Research on the Transition of the Japanese from the Pleistocene to the Jomon and Yayoi Periods' with financial support from the Japan Society for Promotion of Science. This Special Issue of Anthropological Science was planned to gather together some of the research results regarding the anthropology of the Pleistocene of Okinawa, South Japan.

Few Palaeolithic human fossils have been found in the Japanese archipelago, except for the Ryukyu (Okinawa) region. So far, human bones securely dated to before the pottery-associated Jomon period (i.e. older than c. 15000 cal. BP) are known only from a single site on the mainland Japan, namely Hamakita (Suzuki, 1966; Suzuki and Endo, 1966; Kondo and Matsu'ura, 2005). In contrast to most areas of the mainland, where acidic soils hamper bone preservation, the Ryukyu Islands has yielded abundant fossils of extinct deer and other Pleistocene mammalian species because of its karstic nature (Oshiro, 2001). The search for human fossils began in the Ryukyus as early as the 1930s, and two important discoveries were made in the 1960s at the Yamashita-cho Cave I and the Minatogawa Fissure on Okinawa island (Watanabe, 1980).

Juvenile lower limb bones were excavated by Takamiya et al. (1975) from the Yamashita-cho Cave I in 1968. The stratigraphy and radiocarbon dating of charcoal suggested that these bones are c. $32000{ }^{14} \mathrm{C} \mathrm{BP}$, making them currently the oldest human fossils from Japan (Suzuki, 1983). One nearly complete (Minatogawa I) and three partial (Minatogawa II-IV) skeletons, as well as other fragmentary human bones found from the Minatogawa Fissure, are truly significant in terms of the current fossil record of early modern humans from East Asia. The site and morphology of the Minatogawa skeletons were reported in 1982 as a monograph (Suzuki and Hanihara, 1982), in which the skulls, dentitions, and postcranial elements were described by Suzuki, Hanihara and Ueda, and Baba and Endo, respectively (see Kaifu and Fujita, 2011, for a more detailed review of these two sites).

After these important discoveries and initial publications,

* Correspondence to: Yousuke Kaifu, Department of Anthropology, National Museum of Nature and Science, 3-23-1 Hyakunincho, Shinjuku-ku, Tokyo 179-0073, Japan.

E-mail:kaifu@kahaku.go.jp

Published online

in J-STAGE (www.jstage.jst.go.jp) DOI: 10.1537/ase.110620 efforts to find further Pleistocene human remains in the region were continued by some researchers, with successful findings reported from the Miyako and Kume Islands. Pinzaabu (Goat Cave) on Miyako Island was excavated in the early 1980s and a final report on this site was published in 1985 (Department of Education, Okinawa Prefectural Government, 1985). Discoveries from the Pleistocene context included human occipital and parietal fragments with a suggested age of c. $26000{ }^{14} \mathrm{C}$ BP. An infant skeleton was excavated by Hasegawa and collaborators at Shimojibaru Cave on Kume Island in 1982-1983 and 1986, and was assigned a provisional age of c. $15000{ }^{14} \mathrm{C}$ BP (Matsu'ura, 1999). From 1998 to 2001, a new excavation of the Minatogawa Fissure was conducted by a team of archaeologists organized by the local administration (Gushichan Village Board of Education, 2002). Although no additional human remains were discovered, radiocarbon dates obtained by this project did not contradict the terminal Pleistocene ages previously reported for Minatogawa I-IV.

During the 1990 s, various researchers included the Minatogawa I cranium in their multivariate craniometric analyses in order to discuss its genealogical relationships with other terminal Pleistocene and Holocene populations in East Asia (Brace and Tracer, 1992; Wu, 1992; Yamaguchi, 1992; Hanihara, 1994; Lahr, 1995; Brown, 1998). Baba also made his own observations on the Minatogawa I cranium and summarized the general skeletal morphology of the Minatogawa specimens (Baba and Narasaki, 1991; Baba et al., 1998; Baba, 2000). Turner mentioned possible Sundadont characteristics of the Minatogawa dentition (Turner, 1987). These studies generally supported Suzuki's original hypothesis of the southern origin of the Minatogawa people, though raised the question of exactly what population in Southeast Asia was ancestral to them. In regard to the bones from the Yamashita-cho Cave I, Trinkaus and Ruff (1996) published a new comparative analyses that supported the attribution of the bones to an early modern human individual (Suzuki, 1983).

The advances made in the 1990s were significant, but many questions still remain unanswered. Overall, relatively few analyses based on new data were reported in this period: for example, Suzuki's hypothesis of continuous microevolution from the Palaeolithic to Jomon populations in Japan remained virtually unchallenged. Compared to some early modern human fossils from China, such as the Zhoukoudian Upper Cave series, these Japanese fossil materials did not appear so often in discussion of global issues of mod- 
ern human origins and dispersals.

Recently, we have seen growing and renewed interest in the anthropology of the Pleistocene Ryukyu. Field anthropological studies have been actively pursued throughout the past decade (e.g. Doi, 2008), and more recently projects explicitly targeting Pleistocene sites have attracted much attention. Notable recent advances include the discovery of human bones from the Shiraho-Saonetabaru Cave in Ishigaki Island, which were directly dated to $16000-20000{ }^{14} \mathrm{C} \mathrm{BP}$ (Nakagawa et al., 2009). These were, albeit fragmentary, new discoveries of Pleistocene human fossils after a long silence of more than two decades since the last excavations at Pinza-abu and Shimojibaru in the 1980s, and promise further discoveries in the future. Other new field excavations are ongoing (e.g. Okinawa Prefectural Museum and Art Museum, 2009), and projects to review past excavations at the Minatogawa Fissure and other sites are also being organized. This Special Issue was planned in light of these recent trends, with the hope of stimulating further development of this field in Okinawa.

\section{References}

Baba H. (2000) Physical adaptation of the Minatogawa people to island environments. Tropics, 10: 231-241.

Baba H. and Narasaki S. (1991) Minatogawa man, the oldest type of modern Homo sapiens in East Asia. Quaternary Research, 30: 221-230.

Baba H., Narasaki S., and Ohyama S. (1998) Minatogawa hominid fossils and evolution of late Pleistocene humans in East Asia. Anthropological Science, 106 (Suppl.): 27-45.

Brace C.L. and Tracer D.P. (1992) Craniofacial continuity and change: a comparison of late Pleistocene and recent Europe and Asia. In: Akazawa T., Aoki K., and Kimura T. (eds.), The Evolution and Dispersal of Modern Humans in Asia. Hokusensha, Tokyo, pp. 439-471.

Brown P. (1998) The first Mongoloids? Another look at Upper Cave 101, Liujiang and Minatogawa 1. Acta Anthropologica Sinica, 17: 255-275.

Department of Education, Okinawa Prefectural Government (ed.) (1985) Pinza-Abu: Reports on Excavation of the Pinza-Abu Cave. Department of Education, Okinawa Prefectural Government, Naha (in Japanese).

Doi N. (2008) Fieldwork in Okinawa-with the aim to clarify population history of the Ryukyu Islanders. Anthropological Science (Japanese Series), 116: 219-223 (in Japanese)

Gushichan Village Board of Education (ed.) (2002) Minatogawa Fissure Site. Gushichan Village Board of Education, Okinawa (in Japanese).

Hanihara T. (1994) Craniofacial continuity and discontinuity of Far Easterners in the Late Pleistocene and Holocene. Journal of Human Evolution, 27: 417-441.

Kaifu Y. and Fujita M. (2011) Fossil record of early modern humans in East Asia. Quaternary International, doi: 10.1016/ j.quaint.2011.02.017.

Kondo M. and Matsu'ura S. (2005) Dating of the Hamakita human remains from Japan. Anthropological Science, 113: 155-161.

Lahr M.M. (1995) Patterns of modern human diversification: implications for American origins. Yearbook of Physical Anthropology, 38: 163-198.

Matsu'ura S. (1999) A chronological review of Pleistocene human remains from the Japanese Archipelago. In: Omoto K. (ed.), Interdisciplinary Perspectives on the Origins of the Japanese. International Research Center for Japanese Studies, Kyoto, pp. 181-197.

Nakagawa R., Doi N., Nishioka Y., Nunami S., Yamauchi H., Fujita M., Yamazaki S., Katagiri C., Mukai H., Matsuzaki H., Gakuhari T., Takigami M., and Yoneda M. (2009) Pleistocene human remains from Shiraho-Saonetabaru Cave on Ishigaki Island, Okinawa, Japan, and their radiocarbon dating. Anthropological Science, 118: 173-183.

Okinawa Prefectural Museum and Art Museum (ed.) (2009) Excavation of the Hananda-Gama Cave site, Okinawa. Okinawa Prefectural Museum and Art Museum, Naha (in Japanese with English summary).

Oshiro I. (2001) Geological study of quaternary terrestrial vertebrate remains from the Ryukyu Islands. Nohara Tomohide Kyojyu Taikan Kinen Ronbunshu, pp. 37-136.

Suzuki H. (1966) Skeletal remains of Hamakita man. Journal of Anthropological Society of Nippon, 74: 109-136, 172-174 (in Japanese with English summary).

Suzuki H. (1983) The Yamashita-cho man: a late Pleistocene infantile skeleton from the Yamashita-cho Cave (Okinawa). Bulletins et Mémoires de la Société d'Anthropologie de Paris, Série 13, 10: 81-87.

Suzuki H. and Endo B. (1966) Site of Nekata. Journal of Anthropological Society of Nippon, 74: 101-118, 172 (in Japanese with English summary).

Suzuki H. and Hanihara K. (eds.) (1982) The Minatogawa Man. The University of Tokyo Press, Tokyo.

Takamiya H., Kin M., and Suzuki M. (1975) Excavation report of the Yamashita-cho Cave site, Naha-shi, Okinawa. Journal of the Anthropological Society of Nippon, 83: 125-130 (in Japanese with English summary).

Trinkaus E. and Ruff C.B. (1996) Early modern human remains from eastern Asia: the Yamashita-cho 1 immature postcrania. Journal of Human Evolution, 30: 299-314.

Turner C.G., II (1987) Late Pleistocene and Holocene population history of East Asia based on dental variation. American Journal of Physical Anthropology, 73: 305-321.

Watanabe N. (1980) Find sites of the Pleistocene man in Okinawa. Quaternary Research, 18: 259-262 (in Japanese).

Wu X. (1992) The origin and dispersal of anatomically moderhn humans in East and Southeast Asia. In: Akazawa T., Aoki K., and Kimura T. (eds.), The Evolution and Dispersal of Modern Humans in Asia. Hokusensha, Tokyo, pp. 373-378.

Yamaguchi B. (1992) Notes on the human skeleton of the early Jomon phase from the Meotoiwa Rock Shelter site in Ogose, Saitama Prefecture. Bulletin of the National Science Museum, Tokyo, Ser. D, 18: 29-37. 